\title{
A systematic mutation screen of 10 nuclear and 25 mitochondrial candidate genes in 21 patients with cytochrome c oxidase (COX) deficiency shows tRNA ${ }^{\text {Ser(UCN) }}$ mutations in a subgroup with syndromal encephalopathy
}

Michaela Jaksch, Sabine Hofmann, Stephanie Kleinle, Sabina Liechti-Gallati, Dieter E Pongratz, Josef Müller-Höcker, Kerry B Jedele, Thomas Meitinger, Klaus-D Gerbitz

Institute of Clinical Chemistry, Molecular Diagnostics and Mitochondrial Genetics, Academic Hospital Schwabing, Kölner Platz 1, 80804 Munich, Germany $M$ Jaksch

K-D Gerbitz

\section{Department of} Paediatric Genetics, Ludwigs-MaximilianUniversity, Munich,

Germany

$S$ Hofmann

T Meitinger

K B Jedele

Friedrich-Baur-Institut, Munich, Germany

D Pongratz

Institute of Pathology, Munich, Germany J Müller-Höcker

Human Molecular Genetics, Department of Paediatrics and Clinical Research, University of Berne, Switzerland

$S$ Kleinle

S Liechti-Gallati

Correspondence to: Dr Jaksch.

\begin{abstract}
COX deficiency is believed to be the most common defect in neonates and infants with mitochondrial diseases. To explore the causes of this group of disorders, we examined 25 mitochondrial genes (three COX subunit genes and 22 tRNA genes) and 10 nuclear COX subunit genes for disease associated mutations using PCR-SSCP and direct sequencing of polymorphic SSCP fragments. DNA from one patient with severe COX deficiency and with consanguineous parents was entirely sequenced. The patient population consisted of 21 unrelated index patients with mitochondrial disorders and predominant $(n=7)$ or isolated $(n=14)$ COX deficiency.

We detected two distinct tRNA ${ }^{\text {ser(UCN) }}$ mutations, which have been recently described in single kindreds, in a subgroup of four patients with $\mathrm{COX}$ deficiency, deafness, myoclonic epilepsy, ataxia, and mental retardation. Besides a number of nucleotide variants, a single novel missense mutation, which may contribute to the disease phenotype, was found in the mitochondrial encoded COX 1 gene (G6480A). Mutations in nuclear encoded COX subunit genes were not detected in this study. ( $\mathcal{}$ Med Genet 1998;35:895-900)
\end{abstract}

Keywords: cytochrome c oxidase (COX) deficiency; mitochondrial tRNA mutations; myoclonus epilepsy; deafness

Cytochrome c oxidase (COX) is the terminal enzyme (complex IV) of the respiratory chain (RC). It is embedded in the inner mitochondrial membrane and catalyses the transfer of reducing equivalents from cytochrome $\mathrm{c}$ to molecular oxygen, thereby sustaining a $\mathrm{pH}$ gradient and membrane potential. COX deficiency most often presents in infancy as a severe multisystem disorder, with predominant features of encephalopathy and myopathy. ${ }^{12}$ Diagnoses associated with COX deficiency include fatal infantile myopathy, ${ }^{3}{ }^{4}$ benign reversible infantile myopathy, ${ }^{5}$ subacute necrotising encephalomyelopathy or Leigh's disease, ${ }^{6}$ and a variety of syndromic mitochondriopathies. ${ }^{7}$ The COX enzyme is made up of 13 subunits, three encoded by mitochondrial (mt) DNA and 10 of nuclear $(\mathrm{n})$ origin. The mitochondrial encoded subunits are evolutionarily highly conserved and form the catalytic core of the enzyme, and the less conserved nuclear encoded subunits are thought to modulate enzyme activity. ${ }^{8}$

Since components of COX are encoded by mtDNA and nDNA, deficiency may be caused by either a mitochondrial or nuclear mutation. The 13 COX subunits are obvious candidate genes for isolated COX deficiencies; however, only a single mutation in mtDNA encoded COX subunit III has so far been reported in this disorder. ${ }^{10}$ Genes involved in import, assembly, and regulation of mitochondrial subunits are further candidates for $\mathrm{COX}$ deficiency related diseases. A number of pathogenic mutations in mitochondrial tRNA genes have already been described, which are predicted to decrease mitochondrial protein synthesis and thus the levels of those RC complexes partly encoded by the mtDNA (complexes I, III, and IV). ${ }^{11-15}$

In an attempt to find the more common genetic defects in mitochondrial disorders with COX deficiency, we systematically screened both nuclear and mitochondrial candidate genes in 21 patients assigned to different clinical subgroups. Besides a number of nucleotide variants, we found two pathogenic mtDNA tRNA mutations in four unrelated patients and one missense mutation in the COX 1 gene. No nuclear mutations were detected.

\section{Patients and methods}

PATIENTS

Twenty-one unrelated patients presenting with different mitochondrial disorders (table 1) were included in the study.

\section{MEASUREMENT OF RC ACTIVITIES IN SKELETAL}

\section{MUSCLE}

Rotenone sensitive NADH-ubiquinone oxidoreductase (complex I), succinatecytochrome c oxidoreductase (complexes II and III), and COX (complex IV) activities were determined spectrophotometrically according to the methods described by Fischer. ${ }^{16}$ In one patient (patient 15), measurements were performed according to the description of 
Table 1 Clinical and morphological characteristics of patients with COX deficiency

\begin{tabular}{|c|c|c|c|c|c|c|}
\hline $\begin{array}{l}\text { Patient } \\
\text { No }\end{array}$ & $\begin{array}{l}\text { Age of onset/ } \\
\text { (death) }\end{array}$ & Sex & Clinical phenotype & Morphology & $\begin{array}{l}\text { COX rest-activity (\% } \\
\text { from lowest ref value) }\end{array}$ & Family history \\
\hline & & & \multicolumn{4}{|c|}{ Subgroup 1: fatal hypertrophic cardiomyopathy (HCMP) and muscular hypotonia } \\
\hline 1 & Birth (1 mth) & M & HCMP, musc hypotonia & Ragged red fibres & 16 & Parental consanguinity \\
\hline 2 & Birth (1 mth) & $\mathbf{M}$ & HCMP, musc hypotonia & Mitochondrial proliferation & 0 & Single offspring \\
\hline 3 & Birth (5 mth) & $\mathrm{F}$ & HCMP, musc hypotonia & Normal & 64 & One affected, one healthy sister \\
\hline & & & \multicolumn{4}{|c|}{ Subgroup 2: Leigh's disease (subacute necrotising encephalomyelopathy) } \\
\hline 4 & $8 \mathrm{mth}$ & $\mathbf{M}$ & Leigh & ND & 30 & Single offspring \\
\hline 5 & $1 \mathrm{y}(4 \mathrm{y})$ & $\mathrm{F}$ & Leigh & Normal & 51 & Single offspring \\
\hline 6 & $4 \mathrm{y}$ & $\mathbf{F}$ & Leigh & Normal & 27 & Single offspring \\
\hline $\begin{array}{l}7 \\
8\end{array}$ & $\begin{array}{l}\text { Birth (1 mth) } \\
\text { Birth (4 mth) }\end{array}$ & $\begin{array}{l}\mathrm{M} \\
\mathrm{F}\end{array}$ & $\begin{array}{l}\text { Subgroup 3a: fatal infantile myopathy } \\
\text { Musc hypotonia, resp insuff } \\
\text { Musc hypotonia, resp insuff, sepsis }\end{array}$ & $\begin{array}{l}\text { ND } \\
\text { Mitochondrial proliferation }\end{array}$ & $\begin{array}{l}21 \\
53\end{array}$ & $\begin{array}{l}\text { Parental consanguinity } \\
\text { Parental consanguinity }\end{array}$ \\
\hline & & & \multicolumn{4}{|c|}{ Subgroup 3b: slowly progressive generalised muscular hypotonia as predominant feature } \\
\hline 9 & 5 mth & $\mathbf{F}$ & Musc hypotonia, psychomotor retard & Normal & 11 & Single offspring \\
\hline 10 & 5 mth & $\mathrm{F}$ & Musc hypotonia & Normal & 24 & Single offspring \\
\hline 11 & $1 \mathrm{y}$ & $\mathbf{M}$ & Musc hypotonia & Mitochondrial proliferation & 50 & Single offspring \\
\hline 12 & $1 \mathrm{y}$ & $\mathbf{F}$ & Musc hypotonia, psychomotor retard & Mitochondrial proliferation & 17 & Single offspring \\
\hline 13 & $2 \mathrm{y}$ & $\mathbf{M}$ & Musc hypotonia, psychomotor retard & ND & 36 & Single offspring \\
\hline 14 & $6 y$ & $\mathbf{M}$ & Musc hypotonia, resp insuff & Ragged red fibres & 9 & Single offspring \\
\hline & & & \multicolumn{4}{|c|}{ Subgroup 4: myoclonic epilepsy, ataxia, and sensorineural hearing loss } \\
\hline 15 & $1 \mathrm{y}$ & $\mathbf{M}$ & Myocl epilepsy, ataxia, SHL, ment ret & Normal & 29 & Single case \\
\hline 16 & $3 y$ & $\mathrm{~F}$ & Myocl epilepsy, ataxia, SHL, ment ret & Normal & 39 & Brother, mother affected \\
\hline 17 & $8 \mathrm{y}(14 \mathrm{y})$ & $\mathrm{F}$ & Myocl epilepsy, ataxia, SHL, ment ret & Normal & 24 & Single case \\
\hline 18 & 14 y $(36 y)$ & $\mathrm{F}$ & Myocl epilepsy, ataxia, SHL, ment ret & Normal & 73 & Sister, mother affected \\
\hline & & & \multicolumn{4}{|l|}{ Not classified in subgroups $1-4$} \\
\hline 19 & Birth (5 mth) & $\mathrm{F}$ & Recurrent infections, neurol deficits & Normal & 31 & One affected, one healthy sister \\
\hline 20 & Birth (5 mth) & $\mathbf{F}$ & Cerebral atrophy, musc hypotonia & Normal & 12 & Single offspring \\
\hline 21 & $2 \mathrm{y}$ & $\mathbf{M}$ & Ataxia, small for dates & Lipidosis & 17 & Single offspring \\
\hline
\end{tabular}

$\mathrm{SHL}=$ sensorineural hearing loss, $\mathrm{ND}=$ not done.

Krähenbühl et al. ${ }^{17} \mathrm{~A}$ detailed genotypephenotype correlation for index patients 15-18 has been described elsewhere. ${ }^{18}$

DNA ANALYSIS

Total DNA from leucocytes or from small amounts of tissue (muscle, fibroblasts) was obtained using standard extraction procedures (Qiagen). All DNA analyses of index patients were performed on skeletal muscle DNA or RNA, except for patient 5, where fibroblast DNA/RNA was used. The polymerase chain reaction (PCR) and Southern blot analysis were performed as previously described. ${ }^{19}$ For PCR single strand conformation polymorphism (SSCP) analysis, electrophoresis was performed as previously described.$^{20} \mathrm{MtDNA}$ RFLP analysis of first degree relatives of index patients 15,17 , and 18 was performed with leucocyte DNA. MtDNA-RFLP analysis in first degree relatives of index patient 16 was performed on skeletal muscle DNA. To encompass the COX 1-COX 3 genes, we selected 14 primer pairs (upstream and downstream primers possess sequences specific for the light (L) and the heavy $(\mathrm{H})$ strands of the $\mathrm{mtDNA}^{21}$ ): L5873 - 5903, H 6139 - 6162, L 6029 - 6050, H 6139 - 6162, L 6325 -6351, H 6667 - 6639, L 6464 - 6489, H 6824 - 6801, L 6703 - 6730, H 7044 - 7020, L 7019 - 7044, H 7400 - 7378, L 7405 - 7428, H 7666 - 7642, L 7458 - 7487, H 7817 - 7788, L 7760 - 7787, H 8073 - 8049, L 7890 - 7915, H 8280 - 8257, L 7959 - 7982, H 8253 - 8230, L 9138 - 9258, H 9405 - 9382, L 9281 - 9300, H 9630 - 9605, L 9561 - 9588, H 9869 - 9842.

The mitochondrial tRNA genes were amplified using the following primer pairs: $t R N A^{\text {Phe }}$ L: 516 - 536, H: 768 - 748; tRNA ${ }^{\text {Val }}$ L: 1484 1501, H: 1787 - 1760; tRNA ${ }^{\text {Leu(UUR) }}$ L: 3153 -

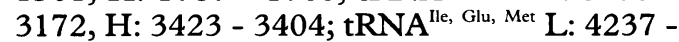

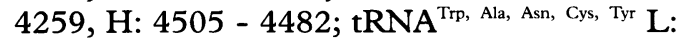

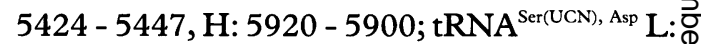
7405 - 7428, H: 7666 - 7642; tRNA ${ }^{\text {Lys }}$ L: 8129 - 8151, H: 8423 - 8395; tRNA ${ }^{\text {Gly }}$ L: $9839-8$ 9867, H: 10288 - 10264; tRNA ${ }^{\mathrm{Arg}}$ L: 10289 .9 10314, H: 10628 - 10601; tRNA ${ }^{\text {His }}$ L: 11997 -O 12019, H: 12209 - 12185; tRNA ${ }^{\text {Ser(AGY), Leu(CUN) }}$ L: 12210 - 12237, H: 12477 - 12450; tRNA ${ }^{\text {Glu }}$ L: 14456 - 14483, H: 14862 - 14842; tRNA $^{\text {Thr, Pro }}$ L: 15806 - 15633, H: 16075 - 16052 .

For sequencing of mtDNA, PCR amplified $\overrightarrow{\overrightarrow{0}}$ DNA was gel purified (Qiagen). Cycle sequencing of mtDNA gene fragments was performed using the Thermosequenase kit (USB) and $\left[{ }^{35} \mathrm{~S}\right] \mathrm{dATP}$ incorporation (ICN).

The PCR amplification of cDNA of nuclear: encoded COX subunits was performed on total RNA extracts from skeletal muscle by a conven-ồ tional guanidine isothiocyanate/phenol isolation method (TRIZOL Reagent, Gibco) and reverse을 transcription method using the 1st strand $>$ cDNA synthesis kit (Boehringer Mannheim). COX 4, COX 5a, COX 6AM, COX 6b, COX N 6c, COX 7AM, COX 7b, COX 7c, and COX 8 cDNAs were amplified using $5^{\prime}$ and $3^{\prime}$ primers according to the published cDNA sequences (EMBL accession number $\mathrm{m} 34600, \mathrm{~m} 22760$, $\mathrm{m} 83308, \mathrm{x} 13923, \mathrm{x} 13238, \mathrm{~m} 83186, \mathrm{x} 16560$, and J04823) to produce fragments encompassing the coding region sequence. $\mathrm{COX} \mathrm{Vb}$ exons 0 were amplified directly from genomic DNA음 (EMBL accession number m59250). PCR was performed using Taq polymerase (Perkin-Elmer) $\stackrel{\vec{\Phi}}{\mathbb{Q}}$ in the presence of $5 \%$ DMSO. The cycle conditions were five minutes at $94^{\circ} \mathrm{C}$, then 35 cycles for 30 seconds at $94^{\circ} \mathrm{C}$, one minute at $60^{\circ} \mathrm{C}$, and응 one minute 30 seconds at $72^{\circ} \mathrm{C}$.

The following primers were used: COX $4: \stackrel{\bar{\partial}}{\supset}$ forward (FW): 27 - 48, FW: 271 - 296, reverse (RV): 325 - 304, RV: 598 - 578. COX 5a: FW: 7 - 26, FW; 209 - 232, RV: 291 - 266, RV: 510 - 487. COX 5b: FW: 10 - 32, FW 930 - 952, FW: 1216 - 1240, FW: 1898 - 1929, RV: 273 - 
Table 2 Respiratory chain activities of skeletal muscle in patients with COX deficiency

\begin{tabular}{|c|c|c|c|c|}
\hline Patients & Complex I & Complex II+III & Complex IV & Citrate synthase \\
\hline \multicolumn{5}{|l|}{ Subgroup 1} \\
\hline 1 & $7.1(0.09)$ & $8.1(0.10)$ & $14.3(0.18)$ & 79.4 \\
\hline 2 & $\star \quad 14.2(0.11)$ & $7.6(0.06)$ & $0.0(0)$ & 124.0 \\
\hline 3 & $15.0(0.23)$ & $6.2(0.10)$ & $58.8(0.93)$ & 63.0 \\
\hline \multicolumn{5}{|l|}{ Subgroup 2} \\
\hline 4 & * $38.9(0.25)$ & $6.3(0.04)$ & $27.0(0.18)$ & 153.0 \\
\hline 5 & ND & ND & $2.6 t$ & $28.0+$ \\
\hline 6 & * $13.2(0.19)$ & $8.6(0.12)$ & $24.0(0.34)$ & 70.0 \\
\hline \multicolumn{5}{|l|}{ Subgroup $3 a$} \\
\hline 7 & $5.6(0.05)$ & $19.4(0.16)$ & $18.7(0.15)$ & 123.0 \\
\hline 8 & $14.7(0.20)$ & $12.8(0.18)$ & $47.6(0.65)$ & 73.0 \\
\hline \multicolumn{5}{|l|}{ Subgroup $3 b$} \\
\hline 9 & $8.8(0.12)$ & $6.3(0.08)$ & $9.7(0.13)$ & 76.1 \\
\hline 10 & $15.7(0.15)$ & $5.0(0.05)$ & $22.0(0.21)$ & 107.0 \\
\hline 11 & * $25.2(0.22)$ & $11.5(0.10)$ & $44.9(0.39)$ & 114.0 \\
\hline 12 & $20.9(0.19)$ & $5.1(0.04)$ & $15.3(0.14)$ & 110.0 \\
\hline 13 & * $41.3(0.29)$ & $18.8(0.13)$ & $32.7(0.23)$ & 143.0 \\
\hline 14 & * $24.9(0.10)$ & $8.9(0.03)$ & $7.9(0.03)$ & 256.0 \\
\hline \multicolumn{5}{|l|}{ Subgroup 4} \\
\hline 15 & $\ddagger$ & $\ddagger$ & $\ddagger$ & $\ddagger$ \\
\hline 16 & $\star \quad 31.2(0.28)$ & $17.8(0.16)$ & $34.9(0.31)$ & 113.0 \\
\hline 17 & * $15.6(0.17)$ & $13.8(0.15)$ & $21.2(0.24)$ & 90.0 \\
\hline 18 & $\star \quad 26.9(0.25)$ & $15.3(0.14)$ & $66.0(0.62)$ & 106.0 \\
\hline \multicolumn{5}{|c|}{ Not classified in subgroups $1-4$} \\
\hline 19 & $\star \quad 35.8(0.28)$ & $17.3(0.14)$ & $27.7(0.22)$ & 128.0 \\
\hline 20 & $12.0(0.16)$ & $8.9(0.12)$ & $10.4(0.14)$ & 72.8 \\
\hline 21 & $30.9(0.24)$ & $9.4(0.07)$ & $15.0(0.12)$ & 127.0 \\
\hline \multicolumn{5}{|l|}{ Reference ranges } \\
\hline Enzyme activity $\$$ & $12.0-40.0$ & $6.0-25.0$ & $90-281$ & $45-105$ \\
\hline Ratiof & $(0.17-0.56)$ & $(0.08-0.45)$ & $(0.90-4.70)$ & \\
\hline
\end{tabular}

^Isolated COX deficiency.

tCOX activity in fibroblasts: activity is expressed as unit $(\mu \mathrm{mol} / \mathrm{min})$ and grams of total protein range: $5.1-22.0 \mathrm{U} / \mathrm{g}$ total protein; coefficient of variation (cv) $17.3 \%$; citrate synthase activity in fibroblasts: range: $8.5-44.0 \mathrm{U} / \mathrm{g}$ total protein; cv $23 \%$.

‡For index patient 15, a combined RC defect of complex I (rest-activity $63 \%$ ) and IV (rest-activity $29 \%$ ) was detected according to the description of Krähenbühl et al. ${ }^{17}$ Owing to different application of methods, enzyme activities are not listed in table 1

$§ R C$ activities in skeletal muscle: activity is expressed as unit $(\mu \mathrm{mol} / \mathrm{min})$ and grams of non-collagen protein (NCP). Complex I (NADH-ubiquinone oxidoreductase; cv 12.3\%), complexes II+III (succinate cytochrome c oxidoreductase; cv 13.6\%), complex IV (COX; cV $8.2 \%$ ), citrate synthase (cv $6.19 \%$ ). Activities differing from the reference range are marked in bold. Control values are given as $95 \%$ confidence interval of the mean.

IAn additional value in parentheses, reflecting the ratio between the activity of the respective RC complexes and the mitochondrial marker enzyme citrate synthase, is given to exclude artificial deficiencies resulting from a lower content of mitochondria in the samples. Ratio is expressed as unit/unit citrate synthase. Ratios differing from the reference range are marked in bold.

Measurements were done in duplicate; average values are given.

253, RV: 1240 - 1214, RV: 1431 - 1403, RV: 2173 - 2148. COX 6AM: FW: 33 - 54, RV: 369 - 346. COX 6b: FW: 21 - 42, RV: 338 - 315. COX 6c: FW: 26 - 48, RV: 348 - 322. COX 7AM: FW: 24 - 46, RV: 337 - 311. COX 7b: FW:38 - 59, FW: 168 - 191, RV: 295 - 271, RV: 423 - 398. COX 7c: FW: 5 - 27, RV: 286 - 262. COX 8: FW: 21 - 43, RV: 297 - 319.

Cycle sequencing of nuclear gene fragments was done using the Dye Primer Cycle Sequencing Ready Reaction Kit (ABI). The sequences were determined with an Applied Biosystems 377 automated sequencer.

\section{QUANTIFICATION OF HETEROPLASMIC MTDNA} MUTATIONS

The mutations $\mathrm{T} 7512 \mathrm{C}$ and $7472 \mathrm{Cins}$ were quantified as previously described. ${ }^{22}{ }^{23}$ The fragments were electrophoresed through a 3\% agarose gel (NuSieve, FMC) and quantified after ethidium bromide staining using the GelPrint2001 Station (MWG Biotech, Ebersberg, Germany) and ONE-DScan 1.0 (Scanalytics, CSPI).

\section{Results}

BIOCHEMICAL AND MORPHOLOGICAL STUDIES

Tables 1 and 2 list the clinical and biochemical features of the 21 unrelated index patients with COX deficiency selected for this study. Patient
5 had a marked reduction in COX activity in fibroblasts; however, no other enzyme was assayed. All other measurements were performed on skeletal muscle biopsies. Isolated COX deficiency was diagnosed in 14 patients, as defined by reduced activity of complex IV (0-73\% of the lowest reference value) and normal activity of complexes I-III. Predominant reduction in COX activity with moderate deficiencies of complexes I-III was observed in six patients. COX activity was completely absent in one case (patient 2). No correlation of COX activity with clinical features, including age of onset, clinical course, and morphology, was observed.

Morphological studies on skeletal muscle probes were available for 18 patients (table 1 ). In most of the patients, normal morphology of mitochondria was found by light and electron microscopy $(60 \%)$, while four cases $(22 \%)$ showed mitochondrial proliferation, two (11\%) had ragged red fibres, and in one case $(5 \%)$ lipid accumulation was seen.

CLINICAL CLASSIFICATION OF PATIENTS AND FAMILY HISTORY

The patients were classified clinically into five subgroups (table 1). Patients 1-3 (subgroup 1) had rapidly progressive hypertrophic cardiomyopathy with death by 5 months of age. Leigh's disease was diagnosed in patients 4-6 of subgroup 2, based on bilateral basal ganglia lesions on MRI. Patients 7 and 8 (subgroup 3a) had fatal infantile myopathy with hypotonia and death from respiratory failure by the age of 4 months. Patients 9-14 (subgroup 3b) manifested slowly progressive hypotonia with other features, including psychomotor retardation, extrinsic asthma, and congenital lactic acidosis. Benign reversible infantile myopathy could not be excluded in this group. Patients $15-18$ had a combination of sensorineural hearing loss, ataxia, myoclonic epilepsy, and mental retardation (subgroup 4). Patients 19-21 had other clinical features which did not fit into the above categories (table 1). Four of the patients, including two of the four in subgroup 4 , had affected first degree relatives. Consanguinity (first cousin parents) was reported in three cases (patients 1,7 , and 8 ). The mothers of patients 7 and 8 both reported miscarriages; patient 7 has two asymptomatic sibs, while patient 1 was an only child. While consanguinity suggests possible autosomal recessive inheritance, maternal inheritance could not be excluded in any of the 21 index patients.

SCREENING OF NUCLEAR COX SUBUNIT GENES COX 4-COX 8 FROM SKELETAL MUSCLE CDNA To confirm that the correct COX cDNAs were amplified (corresponding to the published cDNA sequences), PCR fragments amplified from control muscle cDNA were sequenced. All patients were directly sequenced for mutations in the COX 4 gene and, as with the SSCP results, no variants were detected. Furthermore, all nuclear COX genes were sequenced completely from patient 1 , who presented with a severe and isolated COX defect. (Parental 
Table 3 Evolutionary conservation of nucleotide position 6480 (COX I)

\begin{tabular}{|c|c|c|c|c|c|c|c|c|c|}
\hline $\begin{array}{l}\text { Human mtDNA position } \\
\text { Inserted amino acid (patient 18) } \\
\text { Inserted nucleotide (patient 18) } \\
\text { Conserved amino acids }\end{array}$ & $V$ & $L$ & $I$ & nt 64 & $A$ & $V$ & $L$ & $L$ & $L$ \\
\hline Human & $\begin{array}{l}\text { gtc } \\
\mathrm{V}\end{array}$ & $\begin{array}{l}\text { cta } \\
\text { L }\end{array}$ & $\begin{array}{l}\text { atc } \\
\text { I }\end{array}$ & $\begin{array}{l}\text { aca } \\
\mathrm{T}\end{array}$ & $\begin{array}{l}\text { gca } \\
\text { A }\end{array}$ & $\begin{array}{l}\text { gtc } \\
\mathbf{V}\end{array}$ & $\begin{array}{l}\text { cta } \\
\text { L }\end{array}$ & $\begin{array}{l}\mathrm{ctt} \\
\mathrm{L}\end{array}$ & $\begin{array}{l}\text { ctc } \\
\text { L }\end{array}$ \\
\hline Cow & $\begin{array}{l}\text { gta } \\
\text { V }\end{array}$ & $\begin{array}{l}\text { ata } \\
\mathrm{M}\end{array}$ & $\begin{array}{l}\text { att } \\
\text { I }\end{array}$ & $\begin{array}{l}\mathrm{acc} \\
\mathrm{T}\end{array}$ & $\begin{array}{l}\text { gcc } \\
\text { A }\end{array}$ & $\begin{array}{l}\text { gta } \\
\mathbf{V}\end{array}$ & $\begin{array}{l}\text { cta } \\
\text { L }\end{array}$ & $\begin{array}{l}\text { cta } \\
\text { L }\end{array}$ & $\begin{array}{l}\text { cta } \\
\mathrm{L}\end{array}$ \\
\hline Opossum & $\begin{array}{l}\text { gta } \\
\text { V }\end{array}$ & $\begin{array}{l}\text { ata } \\
\mathrm{M}\end{array}$ & $\begin{array}{l}\text { atc } \\
\text { I }\end{array}$ & $\begin{array}{l}\text { aca } \\
\mathrm{T}\end{array}$ & $\begin{array}{l}\text { gca } \\
\text { A }\end{array}$ & $\begin{array}{l}\text { gta } \\
\mathbf{V}\end{array}$ & $\begin{array}{l}\text { tta } \\
\mathrm{L}\end{array}$ & $\begin{array}{l}\text { ctc } \\
\text { L }\end{array}$ & $\begin{array}{l}\text { ctt } \\
\mathrm{L}\end{array}$ \\
\hline Rattus & $\begin{array}{l}\text { gta } \\
\mathrm{V}\end{array}$ & $\begin{array}{l}\text { cta } \\
\text { L }\end{array}$ & $\begin{array}{l}\text { att } \\
\text { I }\end{array}$ & $\begin{array}{l}\text { aca } \\
\mathrm{T}\end{array}$ & $\begin{array}{l}\text { gcc } \\
\text { A }\end{array}$ & $\begin{array}{l}\text { gtc } \\
\mathbf{V}\end{array}$ & $\begin{array}{l}\text { cta } \\
\text { L }\end{array}$ & $\begin{array}{l}\text { cta } \\
\text { L }\end{array}$ & $\begin{array}{l}\mathrm{ctt} \\
\mathrm{L}\end{array}$ \\
\hline Mus & $\begin{array}{l}\text { gta } \\
\text { V }\end{array}$ & $\begin{array}{l}\mathrm{ctt} \\
\mathrm{L}\end{array}$ & $\begin{array}{l}\text { att } \\
\text { I }\end{array}$ & $\begin{array}{l}\text { aca } \\
\mathrm{T}\end{array}$ & $\begin{array}{l}\text { gcc } \\
\text { A }\end{array}$ & $\begin{array}{l}\text { gta } \\
\mathbf{V}\end{array}$ & $\begin{array}{l}\text { ctg } \\
\text { L }\end{array}$ & $\begin{array}{l}\text { ctc } \\
\text { L }\end{array}$ & $\begin{array}{l}\text { cta } \\
\text { L }\end{array}$ \\
\hline Phoca & $\begin{array}{l}\text { gta } \\
\text { V }\end{array}$ & $\begin{array}{l}\text { tta } \\
\mathrm{L}\end{array}$ & $\begin{array}{l}\text { atc } \\
\text { I }\end{array}$ & $\begin{array}{l}\text { aca } \\
\mathrm{T}\end{array}$ & $\begin{array}{l}\text { gcg } \\
\text { A }\end{array}$ & $\begin{array}{l}\text { gtg } \\
\mathbf{V}\end{array}$ & $\begin{array}{l}\text { ctc } \\
\mathrm{L}\end{array}$ & $\begin{array}{l}\text { cta } \\
\mathrm{L}\end{array}$ & $\begin{array}{l}\text { cta } \\
\text { L }\end{array}$ \\
\hline Baleo & $\begin{array}{l}\text { gtc } \\
\mathrm{V}\end{array}$ & $\begin{array}{l}\text { cta } \\
\mathrm{L}\end{array}$ & $\begin{array}{l}\text { gtc } \\
\mathrm{V}\end{array}$ & $\begin{array}{l}\text { aca } \\
\mathrm{T}\end{array}$ & $\begin{array}{l}\text { gca } \\
\text { A }\end{array}$ & $\begin{array}{l}\text { gta } \\
\mathbf{V}\end{array}$ & $\begin{array}{l}\text { cta } \\
\text { L }\end{array}$ & $\begin{array}{l}\text { ctc } \\
\mathrm{L}\end{array}$ & $\begin{array}{l}\text { cta } \\
\text { L }\end{array}$ \\
\hline $\mathrm{X}$ laevis & $\stackrel{\text { gta }}{\mathrm{V}}$ & $\begin{array}{l}\mathrm{tta} \\
\mathrm{L}\end{array}$ & $\begin{array}{l}\text { atc } \\
\text { I }\end{array}$ & $\begin{array}{l}\text { aca } \\
\mathrm{T}\end{array}$ & $\begin{array}{l}\text { gct } \\
\text { A }\end{array}$ & $\begin{array}{l}\text { gta } \\
\mathbf{V}\end{array}$ & $\begin{array}{l}\text { ctt } \\
\mathrm{L}\end{array}$ & $\begin{array}{l}\text { tta } \\
\mathrm{L}\end{array}$ & $\begin{array}{l}\mathrm{ctt} \\
\mathrm{L}\end{array}$ \\
\hline
\end{tabular}

consanguinity in this patient would suggest autosomal recessive inheritance.)

For the COX 5b gene, four genomic PCR fragments including all exons were screened by SSCP. Sequencing of control fragments and of the patient's fragments only showed four base alterations in intronic regions: 1102 insG, G1118T, A1201T, and A1202T. These base changes do not represent pathogenic mutations, since they were present in all of the sequenced probes $(n=4)$ as well as in the control muscle DNA.

Thus, no disease associated mutations were identified in any of the nuclear encoded COX genes.

SCREENING OF MITOCHONDRIAL COX GENES COX 1-COX 3 FROM SKELETAL MUSCLE DNA

Fourteen PCR amplified DNA fragments (average size $290 \mathrm{bp}$ ) encompassing genes for COX I-III subunits were screened by SSCP. The reproducibility of results was confirmed using control fragments harbouring defined mutations (T9698C, T6776C). A total of seven mutated sites were detected. Of these, six variants represented silent mutations: C6557T, T6671C, and T6776C (COX I) and T9698C, T9716C, and T9899C (COX III). Nucleotide variants in flanking regions were not included in the results $(n=3)$. In index patient 18 and in her less severely affected mother and sister, a homoplasmic G6480A mutation in the COX I gene changing isoleucine to valine at position 193 was detected (in addition to a heteroplasmic pathogenic tRNA mutation as discussed below). The novel G6480A mutation is highly conserved (table 3 ) and was absent in 300 normal controls.

Table 4 MtDNA haplogroup affiliation in patients 15-18

\begin{tabular}{|c|c|c|c|c|c|c|c|c|}
\hline \multirow[b]{2}{*}{$N t$} & \multirow[b]{2}{*}{ Locus } & \multirow[b]{2}{*}{$\begin{array}{l}\text { Base } \\
\text { exchange }\end{array}$} & \multirow[b]{2}{*}{$\begin{array}{l}\text { Amino acid } \\
\text { exchange }\end{array}$} & \multirow[b]{2}{*}{ Cons } & \multicolumn{4}{|c|}{ Index patients } \\
\hline & & & & & \multicolumn{2}{|c|}{ (7472Cins) } & $(C 7512 T)$ & ${ }^{18}$ \\
\hline 7028 & COXI & $\mathrm{C} / \mathrm{T}$ & Syn & Low & - & + & + & + \\
\hline 4216 & ND1 & $\mathrm{T} / \mathrm{C}$ & $\mathbf{Y} / \mathbf{H}$ & Low & - & - & - & + \\
\hline 12308 & $\mathrm{tRNA}^{\mathrm{Leu}(\mathrm{CUN})}$ & $\mathrm{A} / \mathrm{G}$ & - & High & - & - & - & - \\
\hline 12705 & ND5 & $\mathrm{C} / \mathrm{T}$ & Syn & Low & - & - & + & - \\
\hline 15904 & tRNA $^{\text {Thr }}$ & $\mathrm{C} / \mathrm{T}$ & - & Low & - & + & - & - \\
\hline 10463 & tRNA $^{\text {Arg }}$ & $\mathrm{T} / \mathrm{C}$ & - & High & - & - & - & + \\
\hline \multirow{2}{*}{\multicolumn{5}{|c|}{ Haplogroup association according to the classification of ref 24}} & $\Rightarrow$ & & & \pm \\
\hline & & & & & $\mathrm{D}^{\mathrm{C}}$ & $D^{15904}$ & $\mathbf{D}^{12705}$ & $\mathrm{D}^{4216}$ \\
\hline
\end{tabular}

SCREENING OF ALL MITOCHONDRIAL TRNA GENES FROM SKELETAL MUSCLE DNA In total, 13 PCR fragments (average size $310 \mathrm{bp}$ ) encompassing mitochondrial tRNA genes were investigated using SSCP and direct sequencing. For each fragment, control PCR fragments harbouring distinct and known mutations were run together with the patients' probes to test the reproducibility of SSCP conditions. Four tRNA variants were found: $\mathrm{G} 7521 \mathrm{~A}$ in $\mathrm{tRNA}^{\mathrm{Asp}}$, T7547C in tRNA ${ }^{\text {Asp }}, \mathrm{T} 10463 \mathrm{C}$ in tRNA ${ }^{\text {Arg }}$, and $\frac{\mathrm{C}}{\mathrm{T}}$ G15928A in tRNA ${ }^{\mathrm{Thr}}$, the two latter known haplogroup specific polymorphisms. Nucleotide $\triangle$ variants in flanking regions $(n=>10)$ were not included in the results.

In the four patients of clinical subgroup 4 , two separate previously reported pathogenic $\vec{\omega}$ tRNA $^{\text {Ser(UCN) }}$ mutations were identified. An insertion of one cytosine at nt 7472 of the tRNA $^{\text {Ser(UCN) }}$ was found in skeletal muscle DNA is from patients 16 and 17 but not in over 300 . normal controls. Both patients had $100 \%$ mutant DNA, as estimated by additional PCR of based RFLP quantification (detection limit 5\% heteroplasmy). Heteroplasmy of the mutation was found in the matrilineage of both families $z$ (mother and brother of patient 16 were both clinically affected and had $65 \%$ and $75 \% \frac{\Phi}{3}$ mutant mtDNA in skeletal muscle, respec- $\mathbb{\Phi}$ tively; the unaffected mother of patient 17 had $5 \%$ mutant mtDNA in leucocytes).

A tRNA ${ }^{\text {Ser(UCN) }}$ mutation at nt 7512 was detected in patients 15 and 18 . In patient 15 , with infantile onset deafness, myoclonic epilepsy, ataxia, and mental retardation, this mutation was found in homoplasmic form in muscle and blood. Heteroplasmy of the mutation was found in the matrilineage of the fam- $\overrightarrow{\overline{0}}$ ily (an asymptomatic maternal aunt had $75 \%$ and the unaffected brother had $30 \%$ mutant mtDNA in leucocytes, respectively). In patient $18,95 \%$ mutated mtDNA was detected in skeletal muscle; this patient died of multisystemic failure at 36 years of age. His mildly affected mother and sister had a lower degree $\dot{\delta}$ of mutated mtDNA in leucocytes $(40 \%$ and $45 \%$ respectively).

OTHER MTDNA MUTATIONS

Frequent pathogenic mtDNA mutations associated with MELAS (mitochondrial encephalomyopathy, lactic acidosis, and stroke-like epi- $N$ sodes) and MERRF (myoclonus epilepsy and ragged red fibres) syndromes in $\mathrm{tRNA}^{\mathrm{Leu(UUR)}}$ and tRNA $^{\text {Lys }}$ (nt 3243, 3250, 3271, 8344, 8356), aso well as the Leigh's disease associated mutation at $\mathbb{C}$ nt 8993 , were excluded by RFLP analysis, and ${ }^{+}$ large scale rearrangements were excluded using Southern blotting.

HAPLOGROUP AFFILIATION OF INDEX PATIENTS FROM SUBGROUP 4

Haplogroup associations of patients $15-18$ with tRNA $^{\text {Ser(UCN) }}$ mutations were analysed by testing for branching positions at nt 7028, 4216, 12308 12705 , and 15904 , as recently described by our group. ${ }^{19}$ Patients 16 and 17 carrying the 7472 mutation, and patients 15 and 18 carrying the 7512 mutation, belonged to different European mtDNA haplogroups (table 4). 


\section{Discussion}

Most cases of COX deficiency are sporadic and remain unexplained at the molecular genetic level. We therefore first initiated a systematic screening of nuclear genes for structural COX subunits as most obvious nuclear candidate genes for COX deficiency. Twenty-one patients with biochemically defined isolated or predominant COX deficiency were selected for this purpose. We included mitochondrial COX genes as well as mitochondrial tRNA genes in our screening study since family history could not exclude maternal inheritance of the disease in any of our patients.

A genotype-phenotype correlation was provided by the finding of $\mathrm{TRNA}$ mutations in each of the four patients in the subgroup with sensorineural hearing loss, ataxia, myoclonic epilepsy, and mental retardation (subgroup 4). This was the only group of patients with any demonstrable pathogenic mutation. Each patient in subgroup 4 had a mutation which affected tRNA ${ }^{\operatorname{Ser}(\mathrm{UCN})}$, patients 16 and 17 with an apparently homoplasmic cytosine insertion at nt 7472 , and patients 15 and 18 with a mutation at nt 7512 (heteroplasmic in patient 18 and apparently homoplasmic in patient 15).

The pathogenicity of these mutations is supported in several ways. First, the mutations were heteroplasmic in the matrilineage of both families. A second indicator of the pathogenicity of these mutations is their different mitochondrial haplogroup affiliations, showing the independent origin of these mutations (table 4). Pathogenic mtDNA mutations arise independently in multiple families, consistent with their occurrence in different haplogroups. ${ }^{24} 25$ In contrast, most polymorphisms are found in strict association with a single mtDNA haplogroup.

The 7472 disease mutation, which presumably changes the secondary structure of the T $\psi C$ loop region, has been described in a heteroplasmic form in a family with myoclonus, sensorineural hearing loss, and ataxia. ${ }^{22}$ Cybrid studies indicated a decrease in oxidative phosphorylation.

The second $t R N A^{\text {Ser(UCN) }}$ mutation at nt 7512 was detected in a further two index patients of subgroup 4 (patients 15 and 18). Nakamura et $a l^{3}$ described a heteroplasmic T7512C mutation in a family with a MELAS/MERRF overlap syndrome, which disrupts a highly conserved base pair in the acceptor stem in the tRNA $^{\text {Ser(UCN) }}$

An unexpected finding was a second mutation, G6480A, in patient 18 and in her mother and sister. This mutation is also mitochondrial in origin but, unlike 7472 and 7512 , occurs in a COX encoding gene. This mutation is located within an evolutionarily conserved part of the COX I gene; however, the presence of both mutations in all affected family members makes it difficult to estimate the relative pathogenicity of each mutation separately.

The lack of mutations in nuclear COX subunit genes in this group is probably significant. There are several possible reasons for this. The sensitivity of our SSCP protocol, although estimated to be $>90 \%,{ }^{20}$ might allow some mutations to be missed.

A common genetic defect in one of the structural COX genes seems less likely since complete sequencing of DNA from a patient with a severe isolated COX deficiency and consanguineous parents, and the patient of Adams $e t a l^{26}$ with Leigh's disease and COX deficiency, was normal. Similarly, no mutation was found in the mitochondrially encoded COX subunits I-III in a series of 18 patients with isolated COX deficiency. ${ }^{27}$

Since no promoter or intron regions were investigated, the screening was incomplete. Future analysis of the genomic intron/exon structure of the nuclear COX genes is important for a complete screening and other candidate genes need to be identified and investigated. Yeast studies show that a substantial number of other nuclear genes are required for mitochondrial COX gene transcription and translation, mitochondrial import, and folding of nuclear encoded COX proteins, subunit assembly, and turnover. ${ }^{28} 29$ To date, most of the human genes corresponding to these proteins are unknown, but rapid and powerful strategies for identifying human mitochondrial genes have recently been reported. ${ }^{30}$

In conclusion, our data indicate that mutations in tRNA ${ }^{\mathrm{Ser}(\mathrm{UCN})}$ are a cause of mitochondrial syndromic encephalopathy with COX deficiency. Further research will be necessary to identify the other gene defects responsible for this complex group of disorders.

The first two authors contributed equally to this work. We thank Dr Oberle, Dr G P Ramelli, Dr S Krähenbühl, Dr K Rösler, Dr J-M Burgunder, Professor Gosztony, Professor Gulotta, and Dr $M$ Weissert for their clinical and pathological investigations. D $M$ Doerner provided valuable advice on the manuscript. Th excellent technical assistance of A Hedbloom, A Holfert, S Aholt, S Mertens, and A Paprotta is gratefully acknowledged. This work was supported by grants from the Deutsche Forscungem rium fur Bildung und Forschung (01KW $9605 / 4$ ), and by the

1 DiMauro S, Lombes A, Nakase $\mathrm{H}$, et al. Cytochrome c oxidase deficiency. Pediatr Res 1990;28:536-41.

2 Munnich A, Rötig A, Chretien D, Saudubray JM, Cormier V, Rustin P. Clinical presentations and laboratory investigations in respiratory chain deficiency. Eur 7 Pediatr 1996;155:262-74.

3 Van Biervliet JP, Bruinvis L, Ketting D, De Bree PK, Van der Heiden $C$, Wadman SK Hereditary mitochondrial myopathy with lactic acidemia, a De Toni-Fanconi-Debre myopathy with lactic acidemia, a De Toni-Fanconi-Debre
syndrome, and a defective respiratory chain in voluntary syndrome, and a defective respiratory chain in
striated muscles. Pediatr Res 1977;11:1088-93.

4 DiMauro S, Mendell JR, Sahenk Z, et al. Fatal infantile mitochondrial myopathy and renal dysfunction due to cytochrome-c-oxidase deficiency. Neurology 1980;30:795804.

5 DiMauro $S$, Nicholson JF, Hays $A P$, Eastwood $A B$, Koenigsberger R, DeVivo DC. Benign infantile mitochondrial myopathy due to reversible cytochrome c oxidase drial myopathy due to reversible cytochrome
deficiency. Trans Am Neurol Assoc 1981;106:205-7.

6 Willems JL, Monnens LA, Trijbels JM, et al. Leigh' encephalomyelopathy in a patient with cytochrome oxidase deficiency in muscle tissue. Pediatrics 1977;60:850

7 Shoffner JM, Wallace DC. Oxidative phosphorylation diseases. In: Scriver CR, Beaudet AL, Sly WS, Valle D, eds. The metabolic and molecular basis of inherited disease. Vol 1 7th ed. New York: McGraw-Hill, 1995:1535-609.

8 Capaldi RA. Structure and function of cytochrome c oxidase. Annu Rev Biochem 1990;59:569-6.

9 Taanman JW. Human cytochrome c oxidase: structure, function, and deficiency. $\mathcal{F}$ Bioenerg Biomembr 1997;29:151 63.

10 Keightley JA, Hoffbuhr KC, Burton MD, et al. A microdeletion in cytochrome $c$ oxidase (COX) subunit III associated with COX deficiency and recurrent myoglobinuria. Nat Genet 1996;12:410-16.

11 Yoon KL, Aprille JR, Ernst SG. Mitochondrial tRNA(thr) mutation in fatal infantile respiratory enzyme deficiency. Biochem Biophys Res Commun 1991;176:1112-15. 
12 Tulinius $\mathrm{MH}$, Holme E, Kristiansson B, Larsson NG, Oldfors, A. Mitochondrial encephalopathies in childhood. II Clinical manifestations and syndromes. $\mathcal{F}$ Pediatr 1991;119. 251-9.

13 Hanna MG, Nelson I, Sweeney MG, et al. Congenital encephalopathy and adult-onset myopathy diabetes mellitus: different phenotypic associations of a new heteroplasmic mtDNA tRNA glutamic acid mutation. Am $\mathcal{F}$ Hum Genet 1995;56:1026-33.

14 Santorelli FM, Mak SC, El-Schahawi M, et al. Maternally inherited cardiomyopathy and hearing loss associated with a novel mutation in the mitochondrial tRNA Lys gene (G8363A). Am ₹ Hum Genet 1996;58:933-9.

15 Hao H, Moraes CT. Functional and molecular mitochondrial abnormalities associated with a $\mathrm{C}>\mathrm{T}$ transition at $\mathrm{n}$ position 3256 of the human mitochondrial genome. $₹ \mathrm{Biol}$ Chem 1996;271:2347-52.

16 Fischer JC. Mitochondrial myopathies and respiratory chain defects. Dissertation, University of Nijmegen, 1985.

17 Krähenbühl S, Talos C, Wiesmann U, Hoppel CL. Development and evaluation of a spectrometric assay for complex III in isolated mitochondria, tissues and fibroblasts from rats and humans. Clin Chim Acta 1994;230 177-87.

18 Jaksch $M$, Klopstock $T$, Dörner $M$, et al. Progressive myoclonus epilepsy and mitochondrial myopathy associ-
ated with mutations in the tRNA (in press).

19 Hofmann S, Bezold R, Jaksch M, et al. Wolfram (DIDMOAD) syndrome and Leber hereditary optic neuropathy (LHON) are associated with distinct mitochondrial haplotypes. Genomics 1997;39:8-18.

20 Jaksch M, Gerbitz KD, Kilger C. Screening for mitochondrial DNA (mtDNA) point mutations using nonradioactive single strand conformation polymorphism (SSCP) analysis. Clin Biochem 1995;28:503-9.
21 Anderson A, Bankier AT, Barrel BG, et al. Sequence and organization of the human mitochondrial genome. Nature 1981;290:457-65.

22 Tiranti V, Chariot P, Carella F, et al. Maternally inherited $C$ hearing loss, ataxia and myoclonus associated with a novel point mutation in mitochondrial tRNA ${ }^{\text {Ser(UCN) }}$ gene. Hum Mol Genet 1995;4:1421-7.

23 Nakamura M, Nakano S, Goto Y, et al. A novel point mutation in the tRNA ${ }^{\text {Ser(UCN) }}$ gene detected in a family with MERRF/MELAS overlap syndrome. Biochem Biophys Res Commun 1995;214:86-93.

24 Hofmann S, Jaksch M, Bezold R, et al. Population genetics $\overline{\bar{G}}$ and disease susceptibility: characterization of central European haplogroups by mtDNA gene mutations, correlation with $\mathrm{D}$-loop variants and association with disease. Hum Mol Genet 1997;6:1835-46.

25 Torroni A, Huoponen K, Francalacci P, et al. Classification of European $\mathrm{mtDNAs}$ from an analysis of three European populations. Genetics 1996;144:1835-50.

26 Adams PL, Lightowlers RN, Turnbull DM. Molecular के analysis of cytochrome c oxidase deficiency in Leigh's syn- $\vec{C}$ drome. Ann Neurol 1997;41:268-70.

27 Parfait B, Percheron A, Chretien D, Rustin P, Munnich A, Rotig A. No mitochondrial cytochrome oxidase (COX) $\vec{\omega}$ gene mutations in 18 cases of COX deficiency. Hum Genet $O$ 1997;101:247-50.

28 Grivell LA. Nucleo-mitochondrial interactions in mitochondrial gene expression. Crit Rev Biochem Mol Biol 1995; 30:121-64.

29 Schatz G. Mitochondria: beyond oxidative phosporylation. Biochim Biophys Acta 1995;1271:123-6.

30 Tiranti V, Savoia A, Forti F, et al. Identification of the gene $\infty$ encoding the human mitochondrial RNA polymerase 0 (h-mtRPOL) by cyberscreening of the expessed sequence tags database. Hum Mol Genet 1997;6:615-25. 